Portland State University

PDXScholar

\title{
Wood Microsites at Timberline-Alpine Meadow Borders: Implications for Conifer Seedling Regeneration and Alpine Meadow Conifer Invasion
}

\author{
Adelaide C. Johnson \\ U.S.D.A., Forest Service, Pacific Northwest Research Station, Forestry Sciences Laboratory \\ J. Alan Yeakley \\ Portland State University, yeakley@pdx.edu
}

Follow this and additional works at: https://pdxscholar.library.pdx.edu/esm_fac

Part of the Environmental Sciences Commons, and the Forest Management Commons Let us know how access to this document benefits you.

\footnotetext{
Citation Details

Johnson, Adelaide C., and J. Alan Yeakley. "Wood Microsites at Timberline-Alpine Meadow Borders: Implications for Conifer Seedling Regeneration and Alpine Meadow Conifer Invasion." Northwest Science 87(2):140-160.
}

This Article is brought to you for free and open access. It has been accepted for inclusion in Environmental Science and Management Faculty Publications and Presentations by an authorized administrator of PDXScholar. Please contact us if we can make this document more accessible: pdxscholar@pdx.edu. 


\title{
Wood Microsites at Timberline-Alpine Meadow Borders: Implications for Conifer Seedling Regeneration and Alpine Meadow Conifer Invasion
}

\begin{abstract}
The importance of climate warming on forests is recognized worldwide and has increased attention on the significance of both timberline advance and alpine meadow invasion by forests. Successful seedling regeneration in alpine meadows depends on availability of suitable substrates, or microsites, for seedling establishment. We sought to determine whether wood microsites (i.e., nurse logs), which are regeneration sites in Pacific Northwest subalpine forests, promoted regeneration at timberline-alpine meadow borders. To determine the ecological role of wood microsites, we examined mechanisms forming wood microsites; compared density, survival, and percent nitrogen content of seedlings growing on wood microsites to adjacent soil substrates; and compared substrate moisture, temperature, and percent nitrogen content. Wood microsites, at 13 of 14 randomly selected sites, were characterized by highly decayed downed wood ( $>75 \%$ decay class five) originating from tree fall (66\%), snow avalanches (17\%), forest fires (15\%), and by human cutting (2\%). Although no differences in percent nitrogen content were detected, greater seedling densities, greater seedling survival, higher temperatures, and higher moisture contents were found on wood microsites compared to adjacent soil. We suggest that greater seedling density and seedling survival on wood microsites was associated with factors including heightened moisture and increased temperature. Assuming sustained downed wood input from timberline trees and continued viable seed input, we expect wood microsites will facilitate accelerated alpine meadow conifer invasion via wood microsites associated with climate warming.
\end{abstract}

Keywords: regeneration, alpine meadow invasion, disturbance, wood microsites, seedlings

\section{Introduction}

The importance of climate warming on forests is recognized worldwide and has increased attention on the significance of both timberline advance and alpine meadow invasion by forests (Franklin et al. 1971, Rochefort et al. 1994, Körner 2003, Wather 2003, Holtmeier and Broll 2005). Timberline, one of three areas included in the alpine tree ecotone (ATE), represents a line between continuous forest below and area of tree line and krummholtz above (Wardle 1973, Tranquillini 1979, Holtmeier 2003, Hasselquist et al. 2005). Timberline is often adjacent to alpine meadows (upper parklands) having both isolated and groups of seed-generated and clonal-regenerated trees. Seed dispersal, germination, and seedling establishment must

\footnotetext{
${ }^{1}$ Author to whom correspondence should be addressed: Email: ajohnson03@fs.fed.us
}

occur well in advance of any permanent changes in the spatial distribution pattern of mature forests (Noble 1993, Smith et al. 2003, Zens and Peart 2003). Increase in seed-generated trees and viable seed populations in the ATE is associated with climate warming (Franklin et al. 1971, Rochefort et al. 1994, Korner 1998, Kullman 2006), but successful seedling regeneration in alpine meadows may depend on availability of suitable substrates for seed establishment (Woodward et al. 1995, Peterson 1998, Germino et al. 2002).

Microsites are safe areas of micro relief that help ameliorate local environmental factors limiting seed establishment by providing germinating seedlings with necessary shade, moisture, and temperature (Harper et al. 1961, Eriksson and Ehrlén, 1992, Graae et al. 2011). ATE microsites include convexities, concavities, objects that provide shelter from sun and wind, and 
substrates composed of wood, mineral soil, or rock (Holtmeier and Broll 1992, Rochefort et al. 1994, Moir et al. 1999, Castro et al. 2002, Maher et al. 2005). Microsites range in size from millimeters to meters in diameter. In drier areas of the world, concavity microsites supply seedlings with needed moisture during periods of drought (Mellmann-Brown 2005, Anschlag et al. 2008). Where night frost is common, rocks and trees may alter wind, sun, and long-wave radiation patterns thereby protecting seedlings (Ball et al. 1991, Germino and Smith 1999). In the Pacific Northwest (PNW) where heavy snowpacks are common, regeneration in alpine meadows typically occurs on convex microsites or small mounds. Longer growing seasons, attributed to early snow melting, are typically found on raised surfaces (Lowery 1972, Rochefort and Peterson 1996). Examples of PNW convex microsites are located in alpine meadows of Mt. Rainier, North Cascade Mountains of Washington, and Mt. Bachelor in Oregon (Lowery 1972, Rochefort and Peterson 1996, Harold Zald, personal communication). There, species including subalpine fir (Abies lasiocarpa) and mountain hemlock (Tsuga mertensiana) grow within ericaceous species (e.g., pink mountain heather [Phyllodoce empetriformis], Cascade blueberry [Vaccinium deliciosum]) where favorable physical conditions (e.g., shade, wind protection, soil type, seed catchment), favorable biological environments (e.g., appropriate mycorrhizal fungi, Perry et al. 1990), and/or areas having lower than normal snowpack, provide improved conditions for regeneration (Woodward et al. 1995, Peterson et al. 2002).

Wood microsites, important areas of regeneration below timberline (Christy and Mack 1984, Harmon and Franklin 1989, Gray and Spies 1997, Veblen 1989, Gratzer et al. 1999, Narukawa et al. 2003, Ziolonka and Niklossen 2001, Motta et al. 2006, Baier et al., 2007), may also facilitate regeneration at timberline-alpine borders. Below timberline, factors including wood size, wood decay class, available moisture, and amount of shade determine viability of wood microsites for seedling regeneration (Gray and Spies 1997, Mori et al. 2004, Ziolonka and Niklossen 2001). In lower elevation PNW forests, wood microsites reduce competition, support higher moisture levels, and support longer snow-free periods. These factors enhance germination of western hemlock (Tsuga heterophylla), Pacific redcedar (Thuja plicata), subalpine fir (Abies lasiocarpa), and Engelmann spruce (Picea engelmannii) more than adjacent ground surfaces (e.g., Harmon et al. 1986, Harmon and Franklin 1989, Caza 1993). In mountainous forests of Europe and Japan, wood facilitates Norway spruce (Picea abies), Maries' fir (Abies mariesii), and Veitch's fir (Abies veitchii) generation by reducing destructive effects of snow glide, reducing interspecies competition, increasing mychorrizal populations, and enhancing nutrient concentrations (Eichrodt 1969, Simard et al. 1998, Bauer 2003, Brang et al. 2003, Mori et al. 2004, Baier et al. 2006, Baier et al. 2007). In subalpine forests of the Swiss Alps, spruce were found to grow significantly faster on decaying wood (Baier et al. 2007), and seedlings were assumed to profit from earlier snowmelt (Stockli 1995, Smit et al. 2005) and warmer temperatures (Mayer and Ott 1991). We speculate that many of the positive attributes associated with wood microsites in lower elevation forests would also be present at timberline-alpine meadows to support subalpine fir and mountain hemlock seedling regeneration where suitable downed wood exists.

We developed a conceptual model (Figure 1) to illustrate how alpine meadow conifer invasion on wood microsites likely occurs at PNW timberlinealpine meadows, given four necessary steps: 1) existence of large timberline trees and notable forest disturbances, 2) a climate enabling extensive decay of downed wood, 3) successful germination and survival of seedlings on wood microsites, and 4) growth of trees to maturity. Large trees exist at pristine timberlines. By definition, timberline tree heights range from $6 \mathrm{~m}$ to $>15 \mathrm{~m}$, as compared to treeline, with tree heights $>2 \mathrm{~m}$, but generally $<4$ m (Wardle 1981, Cuevas 2002, Oberhuber 2004). Disturbances including tree fall, snow avalanching, and fire are common at PNW timberlines (Franklin et al. 2002, van Mantgem et al. 2009). Trees likely fall or are transported via these disturbances from timberline to adjacent alpine meadows (Figure 1, step 1). When considering that tree susceptibility to tree fall from wind storms 


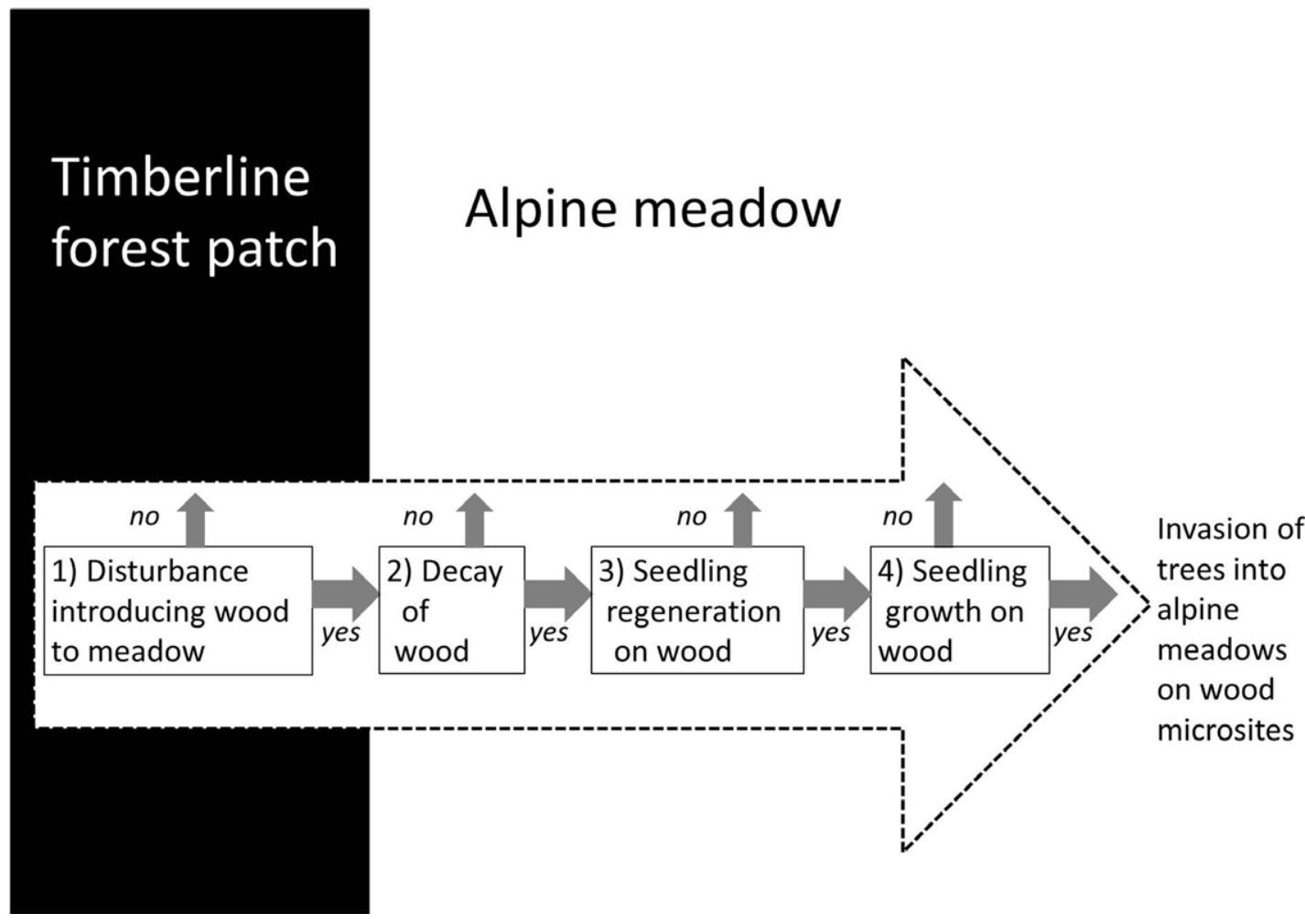

Figure 1. A conceptual model describing wood input, wood decay, seeding regeneration, and seedling growth and invasion of trees in alpine meadow.

is often related to soil-water status and whether soil is frozen, storm meteorology, topography, forest type, amount of tree heart rot decay, and stage of forest stand development (Veblen et al. 1991, Everham and Brokaw 1996, Petola et al. 1999, Lindeman and Baker 2001, Baker et al. 2002, Kulakowksi and Veblen 2002, Kramer et al. 2004, Mitchell 2012); wood input by tree fall is expected to increase with climate warming. Second, extensive decay of downed wood occurs given adequate moisture, temperature, and time (Sollins 1982, Zielonka and Niklasson 2001; Figure 1, step 2). Wood decay rate depends on whether trees are partially decayed before falling, with climatic attributes facilitating decay of wood including high moisture, warm temperatures, and wood species type (Marra and Edmonds 1996, Chen 1999, Hicks 2000, Yatskov et al. 2003). Wood in contact with the ground may decay $50 \%$ faster than elevated wood (Barber and Van Lear 1984). Reduced snowfall, warmer summer tem- peratures, decreased summer precipitation, and longer growing seasons (Leung and Wigmosta 1999, Dale et al. 2001, Mote et al. 2003, Mote 2003a, Mote 2003b, Mote et al. 2005, Westerling et al. 2006, Battin et al. 2007, Markoff and Cullen 2008, Edburg et al. 2012) should increase wood decay rate as long as prolonged droughts do not occur. Third, assuming presence of viable seeds, seedlings germinating on sufficiently rotted wood could establish, given sufficient warmth, moisture, nutrients, and protection from stresses at timberline including wind, frost, and radiation (Hofgaard 1993, Figure 1, Step 3). Limitations to seedling growth could potentially be ameliorated more by wood substrates than adjacent soil substrates. Finally, if seedlings and saplings growing on wood microsites at timberline-alpine meadow borders reach maturity and subsequently fall into meadows and decay, another cycle of conifer invasion into meadows via wood microsites would ensue (Figure 1, Step 4). Awareness 
of eco-physical linkages between processes that introduce wood and possible microhabitats created by wood will help to elucidate processes by which alpine invasion is occurring. Further, this information should enhance predictions of alpine meadow tree invasion rate and should inform forest management in the ATE.

Our study objective was to assess steps 1-3 of our conceptual model to evaluate the ecological role of large downed wood at timberline-alpine meadows borders for facilitating seedling regeneration and enhancing alpine meadow conifer invasion (Figure 1). From a random selection of timberline sites, we addressed the following questions:

1. How prevalent are wood microsites, what are site characteristics where wood microsites are present, and what are the disturbance processes that introduce downed wood?

2. What are the characteristics of wood and wood decay class supporting most conifer seedlings?

3. Do differences exist in wood and adjacent soil substrate moisture, temperature, and nitrogen content. Also, do differences exist in density, survival, and nitrogen content of seedlings growing on wood microsites as compared to adjacent soil substrates?

Lastly, given answers to the previous questions, we assessed the likely rate of tree invasion in alpine meadows and discuss management implications of regeneration on wood substrates.

\section{Study Area}

Using a geographic information system (GIS), 14 sites were chosen from the densest point spacing of possible study locations meeting selection criteria described in the following paragraphs. The GIS used a regular systematic 1-km grid of 1600 potential sample points within the Cascade Range of Washington and Oregon that was spatially intersected with roads, a 10-m digital elevation model (DEM), and a land cover grid (Homer et al. 2004, McNab et al. 2005, Gesch 2007; MRLC NLCD 2001). Initial selection criteria reduced potential sample point locations to 300 based on elevation $(>1400 \mathrm{~m})$ and close proximity to forest edges
(John Chase, personal communication). Because approximately $33 \%$ of these sample points were located in the North Cascades of northern Washington State, this area was selected as representative of the region for research. Site selection criteria included locating sites at least $1 \mathrm{~km}$ away from roads, but requiring no more than a four-hour hike to reach. These criteria reduced the pool of sites to about 50 point locations. Multiple points on the west side of the Cascade Mountains were eliminated due to road closures and multiple points on the east side were eliminated due to known domestic livestock grazing. The chosen 14 point locations span across the North Cascade Mountains. of Washington State in the vicinity of the North Cascades Highway, and also span the west to east precipitation gradient (Figure 2).

Of the 14 sites, seven were located within the mountain hemlock zone on the western portion of the North Cascades (west of longitude $120.700 \mathrm{~W}$ ) and seven were located in the subalpine fir zone on the eastern side of the Cascades (east of longitude $120.7 \mathrm{~W}$ ). Both zones include subzones of closed forest and upper parkland (Franklin and Dyrness, 1979; Figure 2, Table 1). The mountain hemlock zone includes Pacific silver fir (Abies amabilis) and Alaska cedar (Chamecyparis nootkatensis). The subalpine fir zone is more continental with cooler temperatures, and includes Engelmann spruce, lodgepole pine (Pinus contorta), grand fir (Abies grandis), subalpine larch (Larix lyallii), and western white pine (Pinus monticola) (Franklin and Dyrness, 1979). Upper parkland tree invasion, found at all sites, was primarily by mountain hemlock and subalpine fir (Franklin et al. 1971). The forests are under jurisdiction of the Mt. Baker Snoqualmie National Forest on the west, North Cascades Park Complex in the mid-region, and the Okanogan National Forest on the east side. All of the sites are managed as wilderness areas.

The sites spanned a precipitation gradient from $250 \mathrm{~cm} / \mathrm{yr}$ on the western-most site to $150 \mathrm{~cm} /$ $\mathrm{yr}$ on the east side of the Cascades with summer rainfall averaging $20 \mathrm{~cm}$ on the west side and 10 $\mathrm{cm}$ on the east side. Typical of timberlines, elevation increased with increasing distance from the coast (Arno 1984, Körner 1998, Holtmeier 2009) 


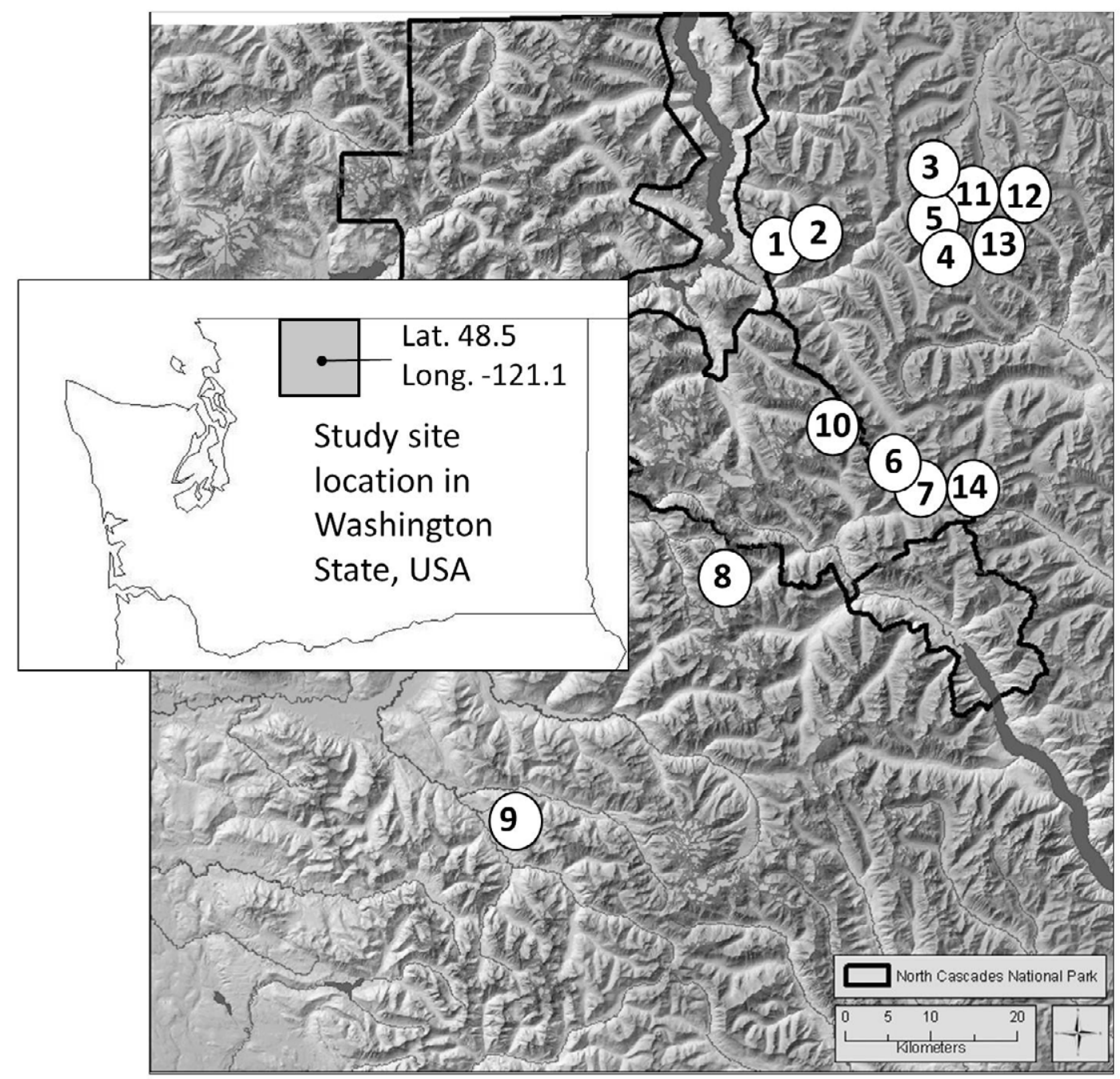

Figure 2. Study site location in Washington State, USA. Western sites are the seven sites located west of site 14 and eastern sites are all sites east of site 7 .

with timberline elevations ranging from $1585 \mathrm{~m}$ on the west side to $1996 \mathrm{~m}$ on the east side. Mean annual temperature averaged $4.1^{\circ} \mathrm{C}$ on the west side and $3.0^{\circ} \mathrm{C}$ on the east side (Thornton et al. 2012, Table 1). Snow typically covered alpine meadows from mid-October to late June or early July with depths exceeding $3.8 \mathrm{~m}$ (USDA, NRCS, SNOTEL 1971-2000).

In general, the geology is volcanic on the west side and sedimentary on the east side, with intrusive volcanics in the mid-range. Soils are well-drained Cryorthods, and have textures ranging from fine sandy loam to sandy gravelly loam. At our sites, organic horizons ranged from 0.5 to $1.0 \mathrm{~cm}$. Total depth of the soil to bedrock ranged from $0.2 \mathrm{~m}$ to $1.0 \mathrm{~m}$ with A-horizons ranging in depth from 0 to $0.2 \mathrm{~m}$ (USDA, NRCS 2008).

\section{Methods}

Site Characteristics and Disturbance Mechanisms Introducing Wood

At each site, one 60-m transect was established along the forest-meadow edge of timberline in 
TABLE 1. Study site characteristics and mean climatic variables. Temperature and rainfall information was obtained from DAYMET (15 y averages).

\begin{tabular}{lcccccccc}
\hline & $\begin{array}{c}\text { Elevation } \\
(\mathrm{m})\end{array}$ & Longitude & Aspect & $\begin{array}{c}\text { Slope } \\
\left({ }^{\circ}\right)\end{array}$ & $\begin{array}{c}\text { Annual } \\
\text { precip. } \\
(\mathrm{mm})\end{array}$ & $\begin{array}{c}\text { Annual } \\
\text { temp. } \\
\left({ }^{\circ} \mathrm{C}\right)\end{array}$ & $\begin{array}{c}\text { Summer } \\
\text { rain } \\
(\mathrm{cm})\end{array}$ & $\begin{array}{c}\text { Summer } \\
\text { temp. } \\
\left({ }^{\circ} \mathrm{C}\right)\end{array}$ \\
\hline $9^{*}$ & 1585 & -121.385 & 10 & 27 & 2370 & 4.0 & 20.0 & 12.6 \\
$8^{*}$ & 1676 & -121.062 & 250 & 35 & 1980 & 5.8 & 14.2 & 15.4 \\
1 & 1981 & -120.903 & 190 & 16 & 1870 & 3.9 & 14.4 & 14.0 \\
$2^{*}$ & 1768 & -120.882 & 140 & 5 & 1800 & 4.1 & 13.7 & 14.3 \\
10 & 1994 & -120.841 & 220 & 13 & 1820 & 2.6 & 12.8 & 13.0 \\
$6^{*}$ & 1875 & -120.761 & 160 & 14 & 1580 & 3.6 & 10.6 & 14.2 \\
7 & 1917 & -120.746 & 350 & 30 & 1520 & 4.1 & 10.1 & 14.7 \\
3 & 1897 & -120.674 & 275 & 27 & 1510 & 3.2 & 11.2 & 13.8 \\
$11^{*}$ & 1996 & -120.668 & 85 & 23 & 1530 & 2.4 & 11.2 & 13.1 \\
14 & 1980 & -120.666 & 330 & 21 & 1440 & 3.0 & 9.6 & 14.3 \\
5 & 1950 & -120.665 & 220 & 18 & 1510 & 2.4 & 11.0 & 13.2 \\
$4 *$ & 1910 & -120.664 & 300 & 21 & 1510 & 2.4 & 11.0 & 13.2 \\
12 & 1905 & -120.637 & 45 & 2 & 1440 & 3.0 & 10.6 & 13.7 \\
13 & 1649 & -120.635 & 150 & 14 & 1390 & 3.9 & 10.0 & 14.6 \\
\hline
\end{tabular}

*Sites where seedling density and survival were determined.

late July and August of 2008. Transects typically started at one side of a forest patch and ran along the timberline edge (Figure 3). At each site, slope gradient and aspect were recorded. Number, diameter, length, and decay class of wood pieces with diameter $>0.15 \mathrm{~m}$ (Sollins et al.1987) were noted when the transect line crossed wood pieces on the ground. Disturbance mechanisms introducing downed wood to alpine meadows were determined and included tree fall, snow avalanches, and fire.

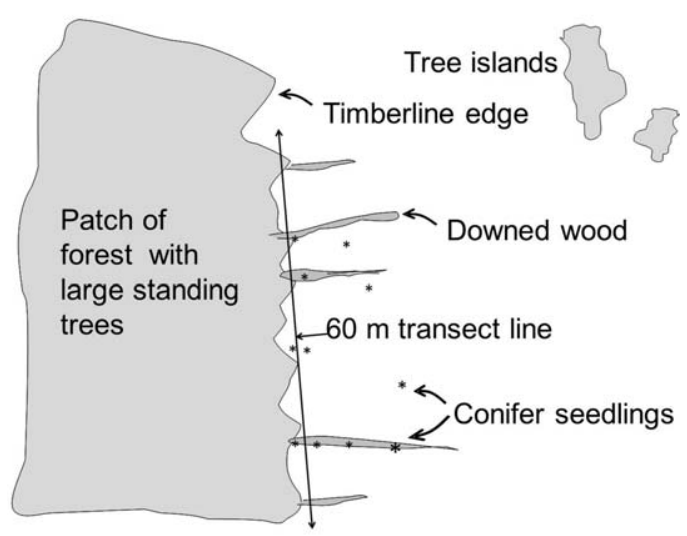

Figure 3. Schematic drawing of a typical study site having a forest patch, adjacent alpine meadow, downed wood, and seedlings.
Tree fall included wind throw (uprooted trees with roots exposed), tree snap, and limb breakage due to snow loading on branches. Snow avalanche activity was inferred from presence of open, nonforested or sparsely forested slopes directly above study areas (Johnson 1987). Fire was indicated by presence of charcoal.

The 14 sites were placed in short-, medium-, and long-shadow length categories based on direction of site aspect with respect to tree patch. Short-shadow length sites included locations on south-facing or north-facing slopes having full exposure to the sun due to lack of tree patches. Medium-shadow sites were located upslope of tree patches on south-facing slopes. The highshadow sites occurred down slope of tree patches on north-facing slopes.

\section{Downed Wood Decay Class Supporting Seedlings}

Downed wood was classified into the following five decay classes: 1) decay class one has branches and twigs present with sound bole; 2) decay class two has sapwood and twigs somewhat decayed, but heartwood and branches may be sound; 3) decay class three has only branch stubs that cannot 
be pulled out and sapwood that can be broken in chunks; 4) decay class four has decayed heartwood and branch stubs that can be easily pulled out; and 5) decay class five has no structural integrity, decayed heartwood, and branch stubs that have rotted away (Maser et al.1979, Sollins 1982). To give an estimate of timberline tree age, increment core samples for tree ageing were extracted at a height of $130 \mathrm{~cm}$ above the ground from the largest trees. Number and species of seedlings growing on downed wood pieces were recorded.

\section{Comparison of Wood and Soil Substrate Temperature, Moisture, Carbon, and Nitrogen}

Wood and soil temperatures were measured midday in July and August among seedlings growing on wood microsites and also on adjacent soils; both measurements were taken at depths of $10 \mathrm{~cm}$. Our subsequent continuous substrate temperature measurements indicated synchronous warming of soils and wood during the day. Generally, the soil measurements were made between 0.3 to $1.0 \mathrm{~m}$ from the wood microsite measurements. These distances ensured that soil temperature measurement were made close, but distant enough from logs to ensure that soil temperature was not influenced by the shade of the log.

Percent organic carbon, percent nitrogen content, $\mathrm{C}: \mathrm{N}$ ratios, and percent water content of wood and soil were determined for two samples on each of the substrate types at each of the 14 sites to compare substrate quality. These samples, with volumes of $31.1 \mathrm{~cm}^{3}$, were taken with a corer $<5 \mathrm{~cm}$ from clusters of young seedlings ( $<3 \mathrm{yr}$ old) on wood and soil along the 60-m transects. Samples were weighed, dried for $48 \mathrm{hrs}$ at 75 ${ }^{\circ} \mathrm{C}$, and then re-weighed to determine change in water content. Dried samples were used for percent carbon content and percent nitrogen content analysis. Percent nitrogen and percent carbon was determined using an automated combustion method (Central Analytical Laboratory Method 9.3) using a LECO model CNS 2000 furnace.

\section{Comparison of Wood and Soil Seedling Density, Survival, and Percent Nitrogen Content}

A subset of six sites was chosen from the original set of 14 sites to compare density, survival, and carbon and nitrogen content of seedlings growing on wood to seedlings growing on adjacent soil substrates. To minimize site variability, we only selected sites with tree fall as the sole mechanism introducing wood to alpine meadows. This ensured that downed wood was generated in situ from the area immediately adjacent timberline edge, as opposed to being transported from a higher elevation by snow avalanches. Of the six sites, three were located on the west side and three were located on the east side of the Cascade Mountains. All seedlings observed on wood and adjacent soil were young, approximately one to three years in age. Density of seedlings on wood and adjacent soil was compared by computing the total surface area of wood extending out from the timberlinealpine meadow border along the 60-m transects (Figure 4). Then, all seedlings growing on the downed wood were divided by the wood surface area as summarized by the equation:

Density $=\Sigma(\mathrm{n}$ seedlings $/($ mean wood width $*$ length $))$

Because the narrowest ends of downed trees were generally absent due to extensive decay, we assumed this approximation of area was appropriate. Seedlings per area on the ground surface were determined by a stratified sampling design whereby 15 regularly-spaced $0.25 \mathrm{~m}^{2}$ plots were sampled in the timberline-meadow fringe within

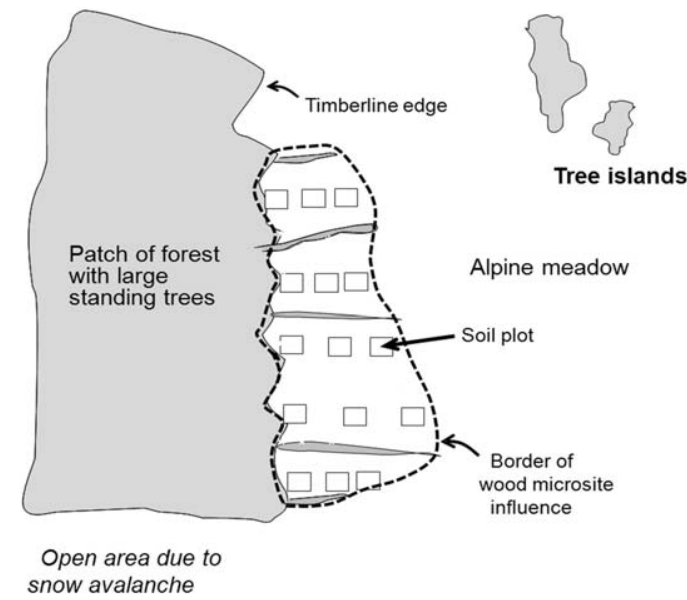

Figure 4. Schematic drawing of stratified sampling used to seedling density on soil. 
the zone of the wood substrates (Figure 4). At distances of $0,15,30,45$, and $60 \mathrm{~m}$, three plots were placed extending out from the timberline into the alpine meadow. The three plots were evenly spaced on the zone of wood influence along the 60-m transect. Soil seedling density was determined by dividing all seedlings growing on soil substrates by the total ground area $\left(3.75 \mathrm{~m}^{2}\right)$ as summarized by the equation:

Soil seedlings density $=\Sigma(\mathrm{n}$ seedlings/area ground $)$

At each of the plots, the number, height, species of seedling, dominant species of herbaceous cover, and amount of area inhibiting tree growth such as rock cover were determined.

To compare seedling survival on wood and soil substrates, a total of 324 one-to three-year old seedlings (162 on wood and 162 on adjacent soil) were marked and reassessed for survival after a three-year period. Each of the six sites had three subsamples comprised of wood and adjacent soil substrate pairs. For each pair, nine seedlings were assessed on wood substrates and nine seedlings were assessed on soil substrates. The nine seedlings were located in clusters of three and were distributed at three locations having different levels of canopy overstory: 1) at timberline, or (highest level of overstory), 2) at mid-range between timberline edge and outermost region of wood influence in alpine meadows (medium level of overstory), and 3) outermost region of wood influence in alpine meadows (lowest level of canopy overstory). Healthy seedlings were transplanted from elsewhere within each of the study sites when extra seedlings were needed to complete this study design (Table 2). Out of 162 seedlings on wood,

TABLE 2. Number of natural (and transplanted) seedlings at study sites.

\begin{tabular}{|c|c|c|c|c|c|c|}
\hline \multirow[b]{2}{*}{ Site } & \multicolumn{2}{|c|}{$\begin{array}{c}\text { Edge of } \\
\text { timberline }\end{array}$} & \multicolumn{2}{|c|}{$\begin{array}{l}\text { Mid-distance } \\
\text { out in meadow }\end{array}$} & \multicolumn{2}{|c|}{$\begin{array}{c}\text { Furthest out } \\
\text { in meadow }\end{array}$} \\
\hline & Wood & Soil & Wood & Soil & Wood & Soil \\
\hline 9 & $9(0)$ & $6(3)$ & $9(0)$ & $2(7)$ & $9(0)$ & $1(8)$ \\
\hline 8 & $5(4)$ & $3(6)$ & $5(4)$ & $5(4)$ & $3(6)$ & $1(8)$ \\
\hline 2 & $6(3)$ & $4(5)$ & $3(6)$ & $3(6)$ & $1(8)$ & $3(6)$ \\
\hline 6 & $5(4)$ & $0(9)$ & $4(5)$ & $1(8)$ & 0 (9) & $0(9)$ \\
\hline 11 & $9(0)$ & $2(7)$ & $9(0)$ & $2(7)$ & $9(0)$ & $1(8)$ \\
\hline 4 & $8(1)$ & $5(4)$ & $6(3)$ & $6(3)$ & $0(9)$ & $4(5)$ \\
\hline
\end{tabular}

100 were natural and 62 transplanted, whereas on soil, 49 were natural and 113 were transplanted. Survival assessments were made separately for natural and transplanted seedlings. To differentiate between seedlings, natural seedlings were marked with one toothpick and transplanted seedlings were marked with two toothpicks. Percent survival was determined when seedlings were approximately three- to six-years old.

Total organic carbon, total nitrogen, and C:N ratios were determined for whole seedlings (all $<3 \mathrm{~cm}$ in ht) growing on wood and soil. At each of the six sites, three to ten whole seedlings were compiled for each of the three locations. Samples were dried for $48 \mathrm{hrs}$ at $35^{\circ} \mathrm{C}$ and then were ground to a fine powder in a Cole-Parmer Analytic Mill (Model 4301). Dried samples were used for percent carbon and percent nitrogen analysis. Percent nitrogen and percent carbon was determined using an automated combustion method (Central Analytical Laboratory Method 9.3) using a LECO model CNS 2000 furnace.

\section{Estimate of Tree Invasion Rate}

We developed the following theoretical equation to approximate rate of tree invasion on wood microsites in alpine meadows:

$$
\mathrm{TI}=\frac{\mathrm{d}_{\text {seed }}}{\mathrm{W}_{\text {mature }}+\mathrm{W}_{\text {decay }}}
$$

where TI is timberline invasion rate $\left(\mathrm{m}^{*} \mathrm{y}^{-1}\right), \mathrm{d}_{\text {seed }}$ is the distance of a growing seedling in alpine meadow beyond timberline $(\mathrm{m}), \mathrm{W}_{\text {mature }}$ is the time necessary for a seedling to grow into a mature tree and fall into an alpine meadow (y), and $\mathrm{W}_{\text {decay }}$ is the mean time to reach decay class five (y). $\mathrm{D}_{\text {seed }}$ was determined from our field observations and $\mathrm{W}_{\text {mature }}$ was determined from the mean age of standing timberline trees in the vicinity of downed wood. We assumed a $\mathrm{W}_{\text {decay }}$ rate of 150 years, a rate found for extensive decay of wood at high-elevation subalpine forests (Hofgaard 1993). Hypothesized alpine conifer invasion rates given climate warming were estimated using decay rates of both 100 years and 50 years, given found decay rates of 44 to 115 years in lower elevation sub-alpine forests (Zielonka and Niklasson 2001, 
Storaunet and Rolstad 2002). We assumed that tree maturity and input occurred at a rate of 100 years given climate warming incorporated an assumed increased input of trees due to catastrophic winds.

\section{Statistical Analysis}

Bar plots with mean values and $95 \%$ confidence intervals were used to display results. When needed, we transformed the data in an attempt to meet assumptions of normality and data variability. We used both parametric (t-test and one-way ANOVA) and non-parametric methods to test for significant differences of response variables between sites associated with wood or soil. Assessments were made to test differences in the response variables temperature, water content, total carbon, nitrogen, and $\mathrm{C}: \mathrm{N}$ ratio of wood and soil with the independent variables including shadow (three categories), aspect (generalized by four cardinal directions), and eastern and western-most sites (split into east-side or west-side categories at longitude 120.700 W, near Rainy Pass; see Table 2). Unless otherwise noted, all statistical tests conducted were separate one-way analysis of variance (ANOVA), with post-hoc multiple comparison tests (Tukey's) used when significant differences were detected. If comparisions were between only two groups, a t-test was used. When comparisons of wood and soil were nonparametric, Wilcoxon's rank sum tests were conducted. Statistical significance was assessed with $\alpha=0.05$ and all statistical analyses were conducted with the R statistics package ( $\mathrm{R}$ Core Development Team 2005).

\section{Results}

\section{Origin and Characteristics of Wood Microsites with Description of Seedlings}

Conifer seedlings grew on downed wood at 13 of 14 randomly selected sites (site 10 had no seedlings on downed wood) at timberline-alpine meadow borders. From the 136 pieces of wood with diameters $>15 \mathrm{~cm}, 41$ had seedlings growing on them. Wood pieces ranged in length from 1.5 to $20 \mathrm{~m}$ ( $7.5 \mathrm{~m}$ average) and wood diameter ranged from 0.15 to $0.80 \mathrm{~m}$ ( $0.52 \mathrm{~m}$ average). Standing mature trees at the edge of timberline adjacent to our study area had diameters of 0.63 $\mathrm{m}$ and surpassed 230 years in age

More wood was introduced to meadows at each site by tree fall ( 27 pieces) than by snow avalanche (7 pieces), fire (6 pieces), or human cutting (1 piece). Tree fall included tree snap (13 pieces), wind throw (6 pieces), knock over by other trees ( 3 pieces), limb and bole breakage likely due to snow (2 pieces), and other unknown causes (5 pieces). Decay class of wood microsites ranged from two to five with $>75 \%$ of the wood microsites in decay class five.

Of the 325 total seedlings growing on wood substrates, 261 were found on decay class five, 59 on decay class four, four on decay class three, and one on decay class two. Seedling species on nurse logs included mountain hemlock, subalpine fir, Pacific silver fir, Alaska cedar, Engelmann spruce, and western larch (Larix occidentalis). Many of the seedlings were $<2 \mathrm{~cm}$ in height, and determining species of seedlings was difficult; however, we estimate that approximately $75 \%$ of the seedlings regenerating on wood were $A b$ ies $s p$. In general, western sites were dominated by mountain hemlock and Abies sp. seedlings, whereas eastern sites were dominated by Abies sp., Engelmann spruce, and western larch seedlings.

Seedlings were found on rotten wood substrates at distances ranging from 0 to $20 \mathrm{~m}$ from timberline edge into alpine meadows. Mean seedling heights and seedling number did not differ significantly by shade category ( $p>0.1$, Figure $5 \mathrm{a}, \mathrm{b})$. No significant differences were found for seedling number by aspect $(p=0.98)$ or by eastside verus westside location $(p=0.66)$.

\section{Comparison of Wood and Soil Substrate Temperature, Moisture, Carbon, and Nitrogen}

Wood substrates had significantly higher summer percent moisture contents than the adjacent soils (means of 38.9 and $17.5 \%$ respectively, t-test, $p$ $<0.01$, Figure $6 \mathrm{a}$ ). Comparisons of percent moisture in wood versus soil substrates as described by aspect, by shade category, and by eastside or westside location were all significantly different $(p<0.01$, Figure 6b, c, d), but wood substrates on 


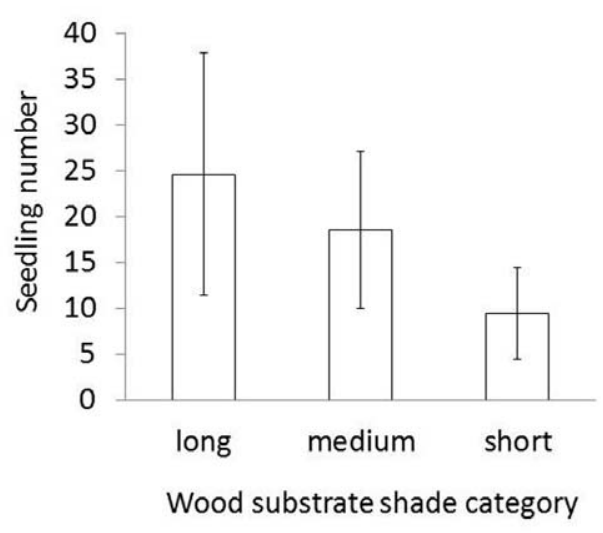

a)

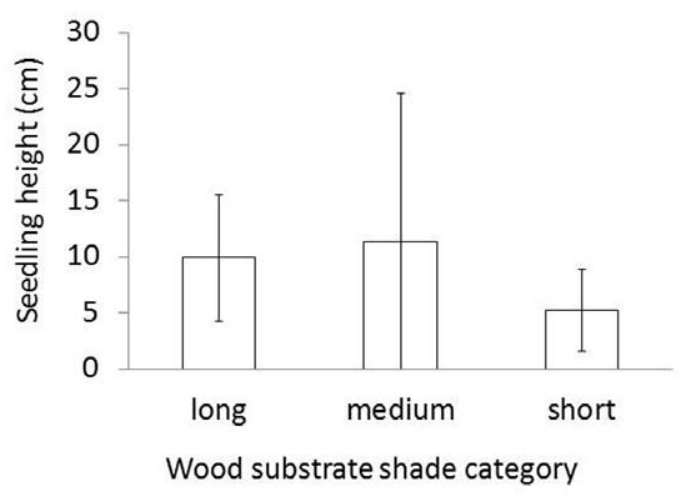

b)

Figure 5. Mean (95\% C.I.) number (a) and b) height of seedlings growing on downed wood substrate by shade category. Short-, medium-, and long-shadow length categories were based upon direction of site aspect with respect to tree patch (see Methods for further description). No statistically significant differences of seedling number or height were found among shade categories.

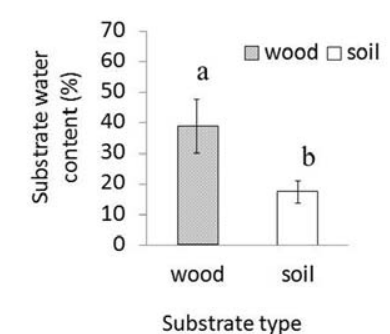

a)

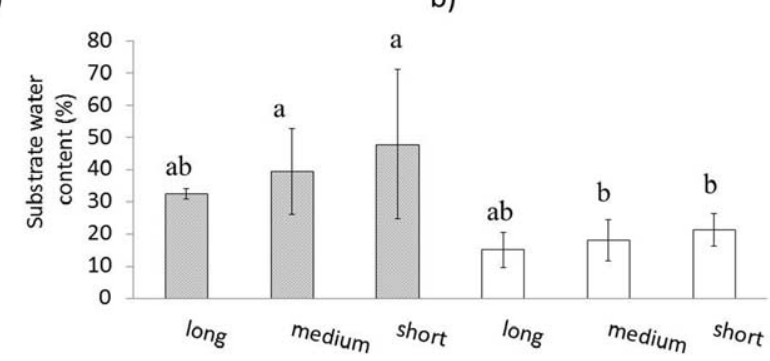

c)

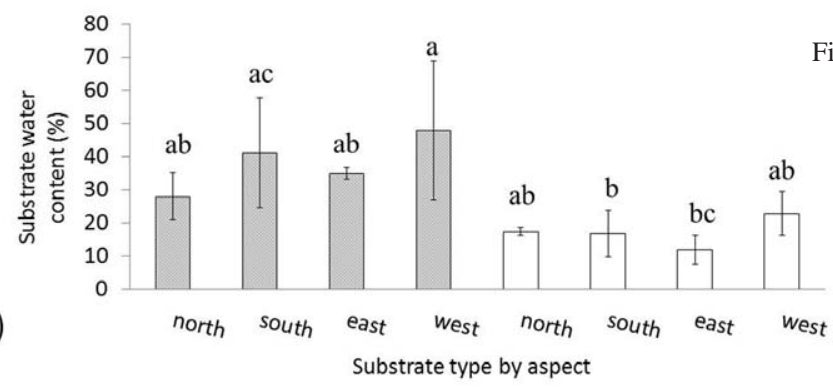

b)

Substrate type by shade category

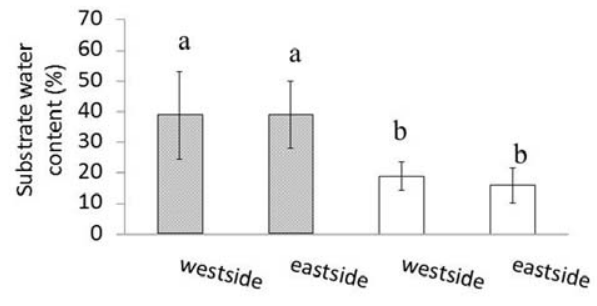

Substrate type by location

Figure 6. Mean (95\% C.I.) of percent water content for wood and soil substrates (a), substrate type and study site location (b; see Figure 1 for description), substrate and shadow category (c), and d) substrate and aspect (d; four directions). Microsites were either wood (shaded bars) or soil (open bars). Letters above bar plots indicate Tukey post-hoc results, where different letters indicate significant differences exist between categories $(p<0.05)$. 
the westside and wood substrates on the eastside did not differ. Post-hoc Tukey tests indicated that wood substrates of the eastern location category (mean moisture content of 38.9\%) were wetter than both eastern soil substrates (mean of $15.9 \%$ ) and western soil substrates (mean of 19.0\%) $(p<$ 0.05 ). Also, wood substrates in the medium-shadow category, all south-facing slopes, were significantly wetter than soil substrates of the medium-shadow category $(p<0.01)$. Wood substrates of the shortshadow category, found on north-facing slopes were significantly wetter (mean of $46.6 \%$ ) than soil substrates of the medium-shadow category $(p=0.03)$. Post hoc tests indicated that wood substrates on south-facing slopes (mean of $41.2 \%$ ) were significantly wetter than south-facing soil substrates (mean of $16.8 \%$ ). Wood substrates on west-facing slopes (mean of $47.9 \%$ ) were significantly wetter than soil substrates on either south or east-facing slopes (mean of $11.9 \%)(p<$ $0.05)$. In comparing wood substrates only or soil substrates only, no significant differences were found between shadow category, east and west locations, or different aspects $(p>0.05)$.

Wood substrates had significantly higher temperatures than the adjacent soils (means of 9.9 and $8.3{ }^{\circ} \mathrm{C}$, respectively, t-test, $p=0.016$, Figure $7 \mathrm{a})$. These differences were not significantly different on east-side versus west-side sites ( $p=$ 0.06 , Figure $7 \mathrm{~b}$ ). When comparing temperature by aspect or shadow length category, no significance differences were found between soil and wood substrates $(p>0.09$, Figure 7c, d).

Significant differences existed between substrates for percent carbon content (mean soil
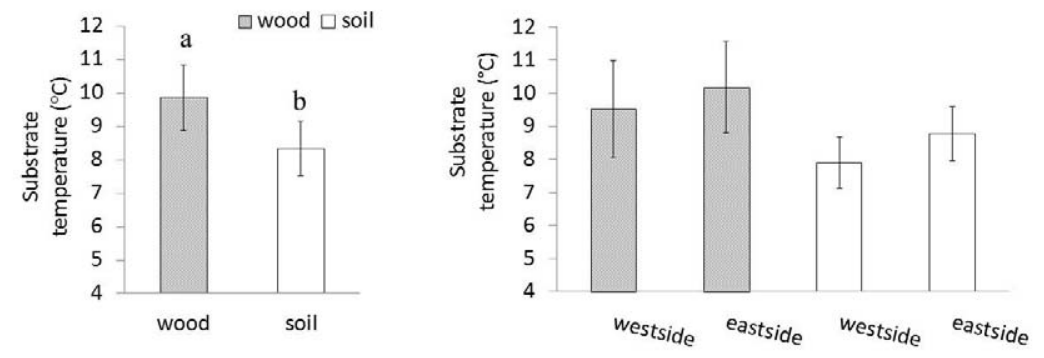

a)

Substrate type

b)

Substrate type by location

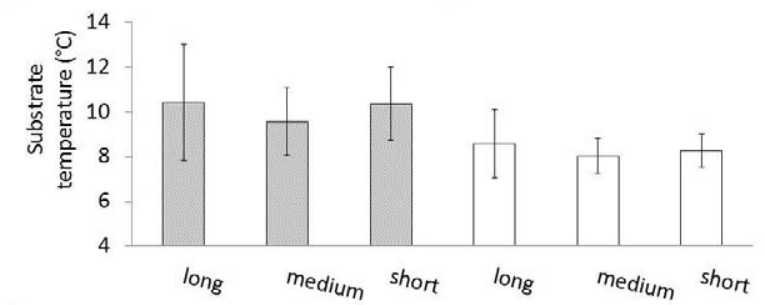

c)

Substrate type by shade category

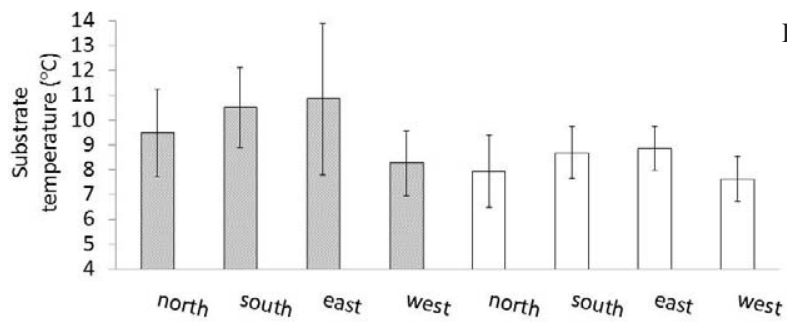

d) Substrate type by aspect
Figure 7. Mean (95\% C.I.) of temperature for wood and soil substrates (a), substrate type and study site location (b; see Figure 1 for description), substrate and shadow category (c), and d) substrate and aspect (d; four directions). Microsites were either wood (shaded bars) or soil (open bars). Letters above bar plots indicate Tukey post-hoc results, where different letters indicate significant differences exist between categories $(p<0.05)$. 


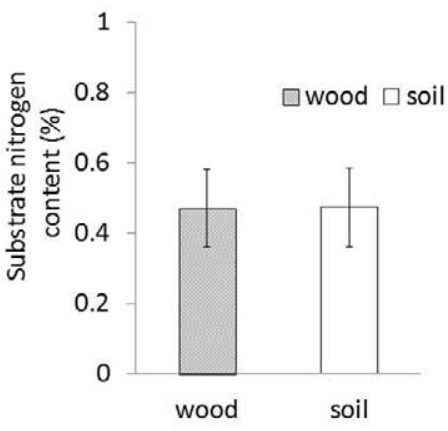

a)

Substrate type

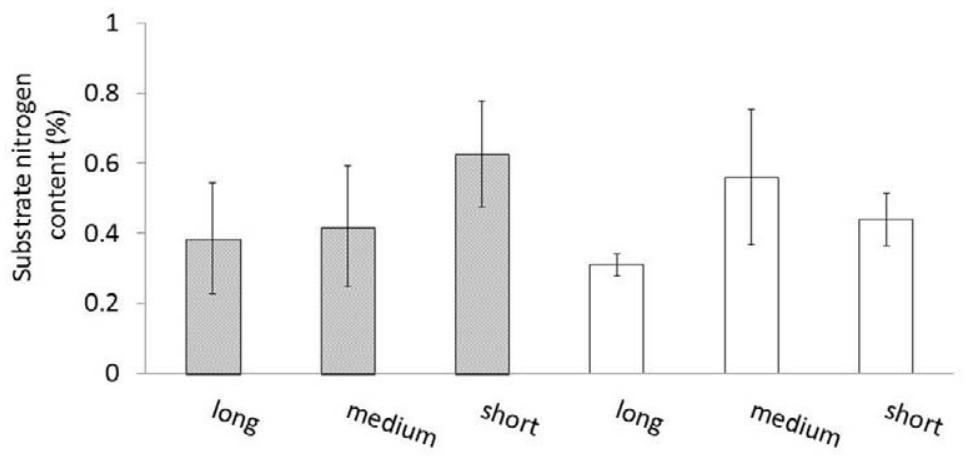

b)

Substrate type by shade category

Figure 8. Mean (95\% C.I.) of total nitrogen for wood and soil substrates (a) and substrate and shadow category (b). Microsites were either wood (shaded bars) or soil (open bars). No significant differences were found for nitrogen content between wood and soil substrates.

carbon content $13.4 \%$, mean wood carbon content $47.16 \%, p<0.01$ ) and $\mathrm{C}: \mathrm{N}$ ratio (mean soil 32.2 , mean wood 126.5, $p<0.001)$. No difference in percent nitrogen content was detected for wood and soils (means of $0.474 \%$ and $0.507 \%$, respectively, t-test, $p=0.59$, Figure $8 \mathrm{a}$ ). No differences in nitrogen were detected for wood and soils when comparing by aspect or by shadow length category $(p>0.5$, Figure $8 b)$.

\section{Comparison of Wood and Soil Seedling Density, Survival, and Nitrogen Content}

Mean seedling density was 6.85 seedlings per $\mathrm{m}^{2}$ on wood and 3.64 seedlings per $\mathrm{m}^{2}$ on soil (Wilcoxon's rank sum test, $p=0.026$, Figure 9a). When separating data by shade category, significant differences were detected $(p=0.022)$ and posthoc Tukey tests indicated significant differences only between seedling density for high-overstory wood microsites and low-overstory soil substrates (density means of 18.2 and 2.3 seedlings per $\mathrm{m}^{2}$, respectively, $p=0.014$ ).

Percent survival was significantly greater for natural seedlings growing on wood than for natural seedlings growing on the adjacent soil substrates (means of 88.3 and 72.7, respectively, Wilcoxon's rank sum test, $p=0.01$, Figure $9 b$ ). Percent survival was significantly greater for transplanted seedlings growing on wood than for seedlings transplanted on soil substrates (means of 18.1 and 12.0, respectively, Wilcoxon's rank sum test, $p=0.03$, Figure 9c). Percent survival was greater for seedlings growing on wood at locations closer to timberline than seedlings growing on soil close to timberline. 

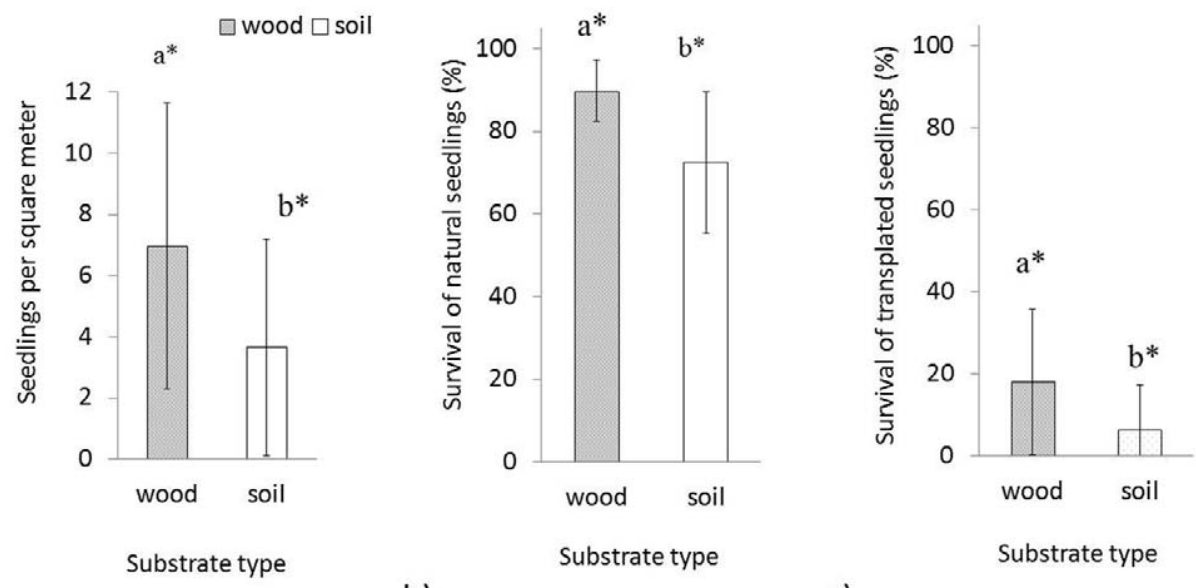

a)

b)

Substrate type

c)
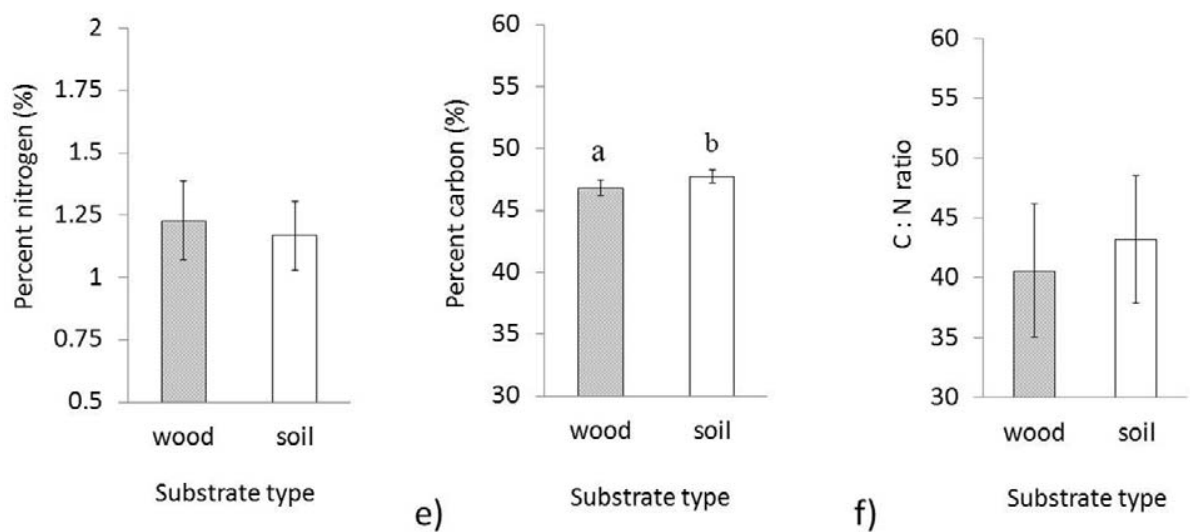

Figure 9. Mean (95\% C.I.) of seedling density (a), and natural seedling survival (b), transplanted seedling survival (c), total percent nitrogen (d), total percent carbon (e), and C:N ratios (f). Microsites were either wood (shaded bars) or soil (open bars). Significant differences are indicated by letters above bar plots. If one of the letters is the same, no statistical difference is indicated. If letters are different, significant differences exist $(p<0.05)$. *Note: Wilcoxon's rank-sum tests.

Percent nitrogen content was similar for seedlings growing in wood and seedlings growing in soil substrates (means of 1.23 and 1.17, respectively, t-test, $p=0.57$, Figure $9 \mathrm{~d}$ ). Overall, percent carbon content of whole seedlings growing in soil was significantly higher than seedlings growing on wood (means of 47.7 and 46.8, respectively, t-test, $p=0.042$, Figure 9e). No difference was found for $\mathrm{C}: \mathrm{N}$ ratio between seedlings growing on wood and soil substrates (means of 43.2 and 40.6, respectively, t-test, $p$ $=0.47$, Figure 9f).

\section{Estimate of Conifer Invasion Rate in Alpine} Meadows

Using equation (3) we estimated a current tree invasion rate between 0.005 to $0.05 \mathrm{~m}^{*} \mathrm{y}^{-1}$. This estimate is based on presence of seedlings growing on rotten wood microsites extending between 2 to $20 \mathrm{~m}$ from timberline into alpine meadows, tree maturity and subsequent input of trees to alpine meadows at 250 years, and a wood decay rate of 150 years. Using climate warming assumptions, a theoretical rate of conifer meadow invasion is increased to $0.13 \mathrm{~m}^{*} \mathrm{y}^{-1}$ (Table 3). 
TABLE 3. Estimates of conifer alpine invasion rate on wood microsites using equation (3). Here, three different climates with various assumed decay rates and tree maturity rates are used. For this example, seedling distance into meadow is assumed to be $20 \mathrm{~m}$.

\begin{tabular}{lcccc}
\hline $\begin{array}{l}\text { Climate } \\
\text { scenarios }\end{array}$ & $\begin{array}{c}\text { Seedling distance } \\
\text { in alpine } \\
\text { meadow, } \mathrm{d}_{\text {seed }}(\mathrm{m})\end{array}$ & $\begin{array}{c}\text { Time to tree } \\
\text { maturity/input, } \\
\mathrm{W}_{\text {mature }}(\mathrm{y})\end{array}$ & $\begin{array}{c}\text { Decay rate, } \\
\mathrm{W}_{\text {decay, }}(\mathrm{y})\end{array}$ & $\begin{array}{c}\text { Resulting alpine } \\
\text { invasion rate, TI } \\
\left(\mathrm{m}^{*} \mathrm{y}^{-1}\right)\end{array}$ \\
\hline Current & 20 & 250 & 150 & 0.05 \\
Warmer & 20 & 100 & 100 & 0.10 \\
Much warmer & 20 & 100 & 50 & 0.13 \\
\hline
\end{tabular}

\section{Discussion}

\section{Wood Input from Timberline to Alpine Meadows}

We found that wood input pattern, ultimately affecting wood microsite location, is influenced by factors that will be altered by climate warming (Figure 1, step 1). Fire, considered the most important disturbance in the Cascade Mountains (Agee 1993, Hemstrom and Franklin 1982, Agee and Skinner 2005, Westerling et al. 2006, Gavin et al. 2007) was apparent at only one study site (located on the eastside of the Cascades) and may have been minimized due to snow avalanches serving as fire breaks (Agee 1993). Although snow avalanches created woody debris trim lines along snow avalanche path borders and deposited wood in alpine meadows, snow avalanches typically transported trees considerable distances down slope. In contrast, wood from timberline trees falling directly into alpine meadows via blow down and wind snap typically created wood microsites at higher elevation timberline locations.

Mature subalpine fir trees (common at our sites) may have been especially prone to wind snap due to weakening by internal wood decay and infestation with fir engraver beetles (Alexander et al. 1984, Hennon 1995, Lewis and Lindgren 1999, McCarthy 2001). With recent outbreaks of large-scale bark beetle infestations, similar in magnitude to that affected by fire facilitated by climate warming (Edburg et al. 2012) and projected increases in more intense storms, more catastrophic inputs of wood can be expected (Dale et al. 2001, Mitchell 2012). Given greater frequency of forest disturbance, a broad band of downed wood will likely be present at timberlinealpine meadow borders in the future.

\section{Decay Characteristics of Wood Microsites at Timberline-alpine Meadows}

Our field observations indicate that the extensive wood decay necessary to facilitate growth of conifer seedlings may not occur at all locations given climate warming (Figure 1, step 2). In some areas, particularly in drier regions where trees die standing, wood can become case hardened whereby compressional strength increases and rotting is inhibited (Erickson 1985, Harmon et al. 1995, Pyle and Brown 1998). Case hardening was apparent at some of our eastside sites where a few downed wood pieces were hard and intact or wood was found in piles of brittle fragments near stumps. These sites did not support seedling regeneration. The type of decay present in downed trees may have affected wood decay at our sites. For example, presence of brown rot is associated with deterioration of wood cellulose only, whereas presence of white rot is associated with decay of both wood cellulose and wood lignin (Blanchette 1991). In general, we expect greater decay of wood particularly at our western-most sites where moisture is greater.

\section{Factors Facilitating Seedling Regeneration on Wood}

We speculate that greater seedling densities and greater seedling survival on wood microsites is attributed, at least in part, to factors including warmer temperature and greater moisture, i.e., elements likely to accelerate alpine meadow invasion with climate warming assuming continued input 
of viable seeds (Figure 1, Steps 3 and 4). Given expected increase in downed wood abundance at timberline-alpine meadow borders, there will be more available substrates for conifer regeneration at shady, protected timberline locations. Here, interrelated factors including higher moisture, lower light, and likely more wind and frost protection enabled successful seedling regeneration. Abies $s p$. seedlings, tolerant of low light levels with roots able to penetrate thick litter layers (Knapp and Smith 1982), were found at all sites. In contrast, Abies sp. seedlings that may have initially established on wood and soil at low-shadow/ low-canopy overstory locations may have been prone to drought and photo-inhibition, a common cause of frost-related death for seedlings growing at high elevation with minimal overstory protection (Ball et al. 1991, Germino and Smith 1999, Germino et al. 2002). Lack of substrate moisture, typically limiting seedling growth (Cui and Smith 1991, Smith and Johnson 2007), is ameliorated by wood substrates. Wood microsite are known to serve as reservoirs during periods of drought (Harmon and Franklin 1989, Amaranthus et al. 1989, Cornett et al. 2000), common during summers in the PNW (Rochefort et al. 1994, Peterson et al. 2002) and expected to increase with climate warming (Markoff and Cullen 2008). Enhanced temperature of wood substrates as compared to adjacent soil substrates can be attributed, at least in part, to the lower albedo of dark wood surfaces. Because mean summer temperature surrounding roots is the most basic ecological factor defining the location of timberlines (Körner and Paulsen 2004), heat enhancement found on wood microsites may have a positive effect on seedling growth.

We speculate that for seedlings growing on wood microsites, more carbon allocation to root production and more colonization of mycorrhizal fungi, may have compensated for low substrate nutrient status. As indicated by seedling excavations (conducted for seedling survival assessments), roots of seedling in wood appeared longer with more tortuous paths than seedlings growing in soil. More colonization of roots by mycorrhizal fungi allow plants to extract sufficient nutrients and from rotting wood (Baier et al. 2006, Fukasawa 2012). Lack of mycorrhyizal infection has been suggested as a factor associated with high conifer seedling mortality rate (Cui and Smith 1991, Hasselquist et al. 2005, Germino et al. 2006). Although nitrate and ammonium (i.e., forms of nitrogen used by plants) were not measured, a $\mathrm{C}: \mathrm{N}$ ratio threshold of 25:1 (with nitrogen limitation above and carbon limitation below, Chapin et al. 2002) suggests nitrogen limitation for all wood microsites, nitrogen limitation for $66 \%$ of soil substrates, and carbon limitation for $33 \%$ of soil substrates. Because plants associated with infertile and cold habitats may respond to nutrient stress by maintaining higher nutrient concentrations, nitrogen level is not necessarily a decisive factor for determining growth at timberline (Chapin 1980, Korner 1989, $\mathrm{Li}$ et al. 2008). For whole seedlings (excluding roots), we found no difference in percent nitrogen and $\mathrm{C}: \mathrm{N}$ ratio, but slightly higher percent carbon content in seedlings growing on soil.

Although not measured in this study, both snow creep and plant completion, minimized on wood microsites as compared to adjacent soil substrates, may have enhanced seedling survival. Snow glide, indicated by downward-sloping toothpicks used to mark seedlings, were very common on soils, but not common on wood. Less snow creep on wood microsites has been found in subalpine forests (Baier et al. 2007). The families Poaceae, Ericaceae, and species including Vaccinium $s p$. and Veratrum viride were commonly found on soil substrates. We speculate that these dense patches of understory foliage at the timberline edge limited survival of conifer seedlings. In contrast, highly decayed wood was commonly devoid of any vegetation besides moss and conifer seedlings.

Wood microsites, important to the survival of young seedlings, are not expected to be important to the survival of older trees. Wood substrates supporting seedlings were highly decayed and often flush with the soil surface. Therefore, we speculate that by the time trees reach maturity wood pieces will be integrated into the soil and wood will not be noticeable. Beyond the 20-m zone influenced by wood microsites, seedlings growing on soil were both clonal and seed generated. Although both trees growing on wood and trees growing on soils are likely to benefit from the longer seasons associated with climate warming, the trees 
growing along closest to the edge of timberline, established mostly on wood microsites, will have the advantage of less wind and less frost stress.

\section{Management Implications and \\ Suggestions for Future Work}

Our finding of increased seedling regeneration on wood microsites at alpine-timberline borders elucidates mechanisms of conifer regeneration above timberline, timing by which alpine invasion is occurring, and also provides guidance to rehabilitation efforts. Our examination of seedling establishment and survival of young seedlings, rather than examination of older resilient trees, gives a clearer understanding of current climatic factors affecting tree invasion in alpine meadows. We found better survival of both natural and transplanted seedlings on wood substrates as compared to adjacent soil substrates; therefore, it is likely that microsites that provide additional warmth and increased moisture ameliorate current climatic limitations for seedling germination at PNW alpine meadows. Natural alpine invasion on wood microsites likely occurs in other regions typified by large trees at timberline-alpine meadows, high precipitation, mild summers, and lack of forest harvesting. Further, these tree-line dynamics provide important feedback mechanisms to the global climate system by altering albedo and carbon storage at high latitudes and high elevations (Leung and Wigmosta 1999, Mote et al. 2003, Wilmking et al. 2006, Malanson et al. 2007, Kirdyanov et al. 2012, Wilmking et al. 2012). Our investigation indicated that wood microsites provide a feedback loop of increased albedo and also increased carbon storage. Interdisciplinary research in the ATE may help reveal the many interrelated positive and negative feedbacks associated with conifer alpine meadow invasion. Wood microsites, providing moister and warmer substrates, can be used in restoration practices. For example, in boreal and alpine areas where histories of fire suppression, forest harvest, and mechanical degradation of alpine meadows have once occurred, newer policies encouraging controlled burns and natural succession processes have benefitted by restoration practices utilizing downed wood and wood fabric (Fattorini 2001,
Vanha-Majamaa et al. 2007). At these locations, wood microsites have effectively enhanced the rate of plant colonization. Our findings indicate that wood substrates may also support restoration in degraded alpine meadows adjacent to high-use recreational trails along timberline-alpine meadows. Because predicted increases in insect abundances and catastrophic winds may exacerbate frequency of downed wood loading in alpine meadows, sustainable long-term supplies of downed wood facilitating conifer regeneration will depend on maintenance of timberline tree populations containing at least a portion of young, healthy trees capable of withstanding various disturbances.

To further assess site factors associated with conifer growth on wood microsites as compared to adjacent soil substrates, four factors are suggested for future research: 1) determination of whether wood substrates accelerate snowmelt and extend the growing season, 2) measurements of possible differences in substrate radiative cooling at night related to level of overstory canopy, 3) physiologic measures of active seedling growth, and 4) assessment of root mycorrhyizal associations.

\section{Conclusion}

We determined that conifer seedling regeneration was facilitated more by wood microsites than by adjacent soil substrates at timberline-alpine meadow borders. Wood microsites had greater seedling density, greater seedling survival, and provided warmer and moister substrates than adjacent soil substrates. Highly rotted wood, primarily originating from tree fall, supported regeneration particularly for Abies sp. Wood has been shown to be a superior site for germinating seedlings, particularly in sites with high shade. We hypothesize that higher seedling density and survival was attributed to greater substrate temperature and moisture, and was also likely supported by mychorryzal associations, less snow glide, and less competition on/in wood microsites. Potential conifer invasion into alpine meadows via wood substrates is dependent on three steps: 1) disturbance processes introducing large wood from timberline to meadows, 2) a climate facilitating wood decay, 3) successful germination and 
survival of seedlings to maturity. Seedling growth on wood microsites is likely to occur in other regions typified by large trees at timberline-alpine meadows, high precipitation, mild summers, and lack of forest harvesting.

\section{Acknowledgements}

Field operations were facilitated by Regina Rochefort, Science Advisor, North Cascades Park Complex. Field work assistance was provided by Wilhelmina Bradley, Elizabeth MacWhinney, Stephanie Engelbrecht, Kate Freund, Michael Liang, Mignone Biven, and Aubrey Hekkers. Michael Hekkers and Kristina Thorneycroft created the maps. John Chase, USDA Forest Service, conducted GIS work integral to creation of a random set of field sites. Laboratory work was

\section{Literature Cited}

Agee, J. K. 1993. Fire Ecology of Pacific Northwest Forests. Island Press, Washington, DC.

Agee, J. K., and C. N. Skinner. 2005. Basic principles of forest fuel reduction treatments. Forest Ecology and Management 211:83-96.

Alexander, R. R., R. C. Shearer, and W. D. Shepperd. 1984. Silvical characteristics of subalpine fir. Rocky Mountain Forest and Range Experiment Station General Technical Report RM-115. Fort Collins, CO.

Amaranthus, M. P., D. Parrish, and D. A. Perry. 1989. Decaying logs as moisture reservoirs following drought and wildfire. In E. Alexander (editor), Proceedings-Stewardship of Soil, Air and Water Resources, Watershed 89, USDA Forest Service General Technical Report R10-MB-77, Juneau, AK. Pp.191-194

Anschlag, K., G. Broll, and F-K. Holtmeier. 2008. Mountain birch seedlings in the tundra ecotone, subarctic Finland: variation in above- and below-ground growth depending on microtopography. Arctic, Antarctic, and Alpine Research 40:609-616.

Arno, S. F. 1984. Timberline. The Mountaineers, Seattle.

Baier, R., R. Ettl, C. Hahn, and A. Göttlein. 2006. Early development and nutrition of Norway spruce (Picea abies [L.] Karst) seedlings on mineral soil, organic layer, and decayed woody debris origin from dolomite sites of the Bavarian Limestone Alps. Annual Forest Science 63:339-348.

Baier, R., J. Meyer, and A. Göttlein. 2007. Regeneration niches of Norway spruce (Picea albies [L.] karst.) saplings in small canopy gaps in mixed mountain forest of the Bavarian Limestone Alps. European Journal of Forest Research 126:11-22. supported, in part, by use of equipment from the University of Alaska Southeast and USDA Forest Service, PNW Research Station, Forestry Sciences Laboratory in Juneau, Alaska. Heather Erickson, Jason Fellman, Rick Edwards, Michael Hekkers, Dave D'Amore, and Paul Hennon increased the clarity of the manuscript through discussions and helpful comments. Statistics advice and review was provided by Ashley Steel and Pat Cunningham, PNW Research Station. Anonymous reviewers from the Northwest Science Journal increased scope and rationale of the study through both careful editing and by advocating a major reorganization of the manuscript. The use of trade names in this paper is for the information and convenience of the reader and does not constitute endorsement by the USDA.

Baker, W. L., P. H. Flaherty, J. D. Lindemann, T. T. Veblen, K. S. Eisenhart, and D. Kulakowski. 2002. Effect of vegetation on the impact of a severe blow down in the southern Rocky Mountains, USA. Forest Ecology and Management 168:63-75.

Ball, M. C., V. S. Hodges, and G. P. Laughlin. 1991. Coldinduced photoinhibition limits regeneration of snow gum at tree-line. Functional Ecology 5:665-668.

Barber, B. L., and D. H. Van Lear. 1984. Weight loss and nutrient dynamics in decomposing woody loblolly pine logging slash. Soil Science Society of America Journal 48:906-910.

Battin, J., M. W. Wiley, M. H. Ruckelshaus, R. N. Palmer, E. Korb, K. K. Bartz, and H. Imaki. 2007. Projected impacts of climate change on salmon habitat restoration. Proceedings of the National Academy of Sciences of the United States of America 104:6720-6725.

Bauer, M. L. 2003. Walddynamik nach Borkenbefall in den Hochlagen des Bayerischen Waldes Ph.D. Dissertation, Lehrstuhlfür Waldbau und Forsteinrichtung, Germany, Munich.

Blanchette, R. A. 1991. Wood-decay fungi. Annual Review of Phytopathology 29:381-98.

Brang, P., J. Moran, P. Puttonen, and A. Vyse, 2003. Regeneration of Picea Engelmannii and Abies lasiocarpa in high-elevation forests of south-central British Columbia depends on nurse logs. The Forestry Chronicle 79:273-279.

Castro, J., R. Zamora, J. A. Hódar, and J. M. Gómez. 2002. Use of shrubs as nurse plants: a new technique for reforestation in Mediterranean mountains. Restoration Ecology 10:297-305.

Caza, C.L. 1993. Woody debris in the forests of British Columbia: a review of the literature and current research. British Columbia Ministry of Forests 
Land Management Report (ISSN 0702-9861; 78), Victoria, B.C.

Chapin, F. S., III. 1980. The mineral nutrition of wild plants. Annual Review Ecological Systems 11:233-260.

Chapin, F. S., III, P. A. Matson, H. A. Mooney. 2002. Principals of Terrestrial Ecosystem Ecology. SpringerVerlag, New York.

Chen, H. 1999. Root decomposition in three coniferous forests: effects of substrate quality, temperature, and moisture. Ph.D. Dissertation, Oregon State University, Corvallis, OR.

Christy, E. J., and R. N. Mack. 1984. Variation in demography of juvenile Tsuga heterophylla across the substratum mosaic. Journal of Ecology 72:75-91.

Cornett, M. W., P. B. Reich, K. J. Puettmann, and L. E. Frelich. 2000. Seedbed and moisture availability determine safe sites for early Thuja occidentalis (cupressaceae) regeneration. American Journal of Botany 87:1807-1814.

Cuevas, J. G. 2002. Episodic regeneration at the Nothofagus pumilio alpine timberline in Tierra del Fuego, Chile. Journal of Ecology 90:52-60.

Cui, M. and M. K. Smith. 1991. Photosynthesis, water relations and mortality in Abies lasciocarpa seedlings during natural establishment. Tree Physiology 8:37-46.

Dale, V. H., L. A. Joyce, S. McNulty, R. P. Neilson, M. P. Ayres, M. D. Flannigan, P. J. Hanson, L. C. Irland, A. E. Lugo, C. J. Peterson, D. Simberloff, F. J. Swanson, B. J. Stocks, and B. M. Wotton. 2001. Climate change and forest disturbances. BioScience 51:723-734.

Edburg, S. L., J. A. Hicke, P. D. Brooks, E. G. Pendall, B. E. Ewers, U. Norton, D. Gochis, E. D. Gutmann, and A. J. H. Meddens. 2012. Frontiers in Ecology and the Environment 10:416-424.

Eichrodt, R. 1969. Über die Bedeutung von Moderholzfür die natürliche Verjüngungim subalpinen Fichtenwald. BeihSchweizZorstw 45:122.

Erickson, H. E., R. L. Edmonds, and C. E. Peterson. 1985. Decomposition of logging residues in Douglas-fir, western hemlock, Pacific silver fir, and ponderosa pine ecosystems. Canadian Journal of Forest Research 15:914-921.

Eriksson, O. and J. Ehrlén. 1992. Seed and microsite limitation of recruitment in plant populations. Oecologia 91:360-364.

Everham, III E. M., and N. V. L. Brokaw. 1996. Forest damage and recovery from catastrophic wind. Botanical Review 62:113-85.

Fattorini, M. 2001. Establishment of transplants on machine-graded ski runs above timberline in the Swiss Alps. Restoration Ecology 9:119-126.

Franklin, J. F., W. H. Moir, G. W. Douglas, and C. Wiberg. 1971. Invasion of subalpine meadows by trees in the cascade range of Washington and Oregon. Arctic and Alpine Research 3:215-224.
Franklin, J. F., and C. T. Dyrnes. 1979. Natural Vegetation of Oregon and Washington. USDA Forest Service General Technical Report PNW-8. Portland, OR.

Franklin, J. F., T. A. Spies, R. van Pelt, A. Carey, D. Thornburgh, D. R. Berg, D. B. Lindenmayer, M. Harmon, W. Keeton, and D. C. Shaw. 2002. Disturbances and the structural development of natural forest ecosystems with some implications for silviculture. Forest Ecology and Management 155:399-423.

Fukasawa, Y. 2012. Effects of wood decomposer fungi on tree seedling establishment on coarse woody debris. Forest Ecology and Management 266:232-238.

Gavin, D. G., D. J. Hallett, F. S. Hu, K. P. Lertzman, S. J. Prichard, K. K. Brown, J. A. Lynch, A. Bartlein, and D. L. Peterson. 2007. Forest fire and climate change in western North America: insights from sediment charcoal records. Frontiers in Ecology and the Environment 5:499-506.

Germino, M. J., and M. K. Smith. 1999. Sky exposure, crown architecture, and low-temperature photoinhibition in conifer seedlings at alpine treeline. Plant, Cell, and Environment 22:407-415.

Germino, M. J., M. K. Smith, and C. A. Resor. 2002. Conifer seedling distribution and survival in an alpinetreeline ecotone. Plant Ecology 162:157-168.

Germino, M. J., N. J. Hasselquist, T. M. McGonigle, W. K. Smith, and P. P. Sheridan. 2006. Colonization of conifer seedling roots by fungal mycelium in an alpine-treeline ecotone. Canadian Journal of Forest Research 36:901-909.

Gesch, D. B. 2007. The National Elevation Dataset, In D. Maune (editor), Digital Elevation Model Technologies and Applications: The DEM User's Manual, 2nd Edition: Bethesda, Maryland, American Society for Photogrammetry and Remote Sensing.

Graae, B., R. Ejrnæs, S. Lang, E. Meineri, P. Ibarra, and H. Bruun. 2011. Strong microsite control of seedling recruitment in tundra. Oecologia 166:565-576.

Gratzer, G., P. B. Rai, and G. Glatzel. 1999. The influence of the bamboo Yushaniamicrophylla on regeneration of Abies densa in central Bhutan. Canadian Journal of Forest Research 29:1518-1527.

Gray, A. N., and T. A. Spies. 1997. Microsite controls on tree seedling establishment in conifer forest canopy gaps. Ecology 78:1458-2473.

Harmon, M. E., and J. F. Franklin. 1989. Tree seedlings on logs in Picea-Tsuga forests of Oregon and Washington. Ecology 70:48-59.

Harmon, M. E., D. F. Whigham, J. Sexton, and I. Olmsted. 1995. Decomposition and mass of woody detritus in the dry tropical forests of the northeastern Yucatan Peninsula, Mexico. Biotropica 27:305-316.

Harmon, M. E., J. F. Franklin, F. J. Swanson, P. Sollins, S. V. Gregory, J. D. Lattin, N. H. Anderson, S. P. Cline, N. G. Aumen, J. R. Sedell, G. W. Lienkaemper, K. Cromack, and K. W. Cummins. 1986. Ecology of coarse woody debris in temperate ecosystems Advances in Ecological Research 15:133-302. 
Harper, J. L., J. N. Clatworthy, I. H. McNaughton, and G. R. Sagar. 1961. The evolution and ecology of closely related species living in the same area. Evolution 15:209-227.

Hasselquist, N., M. J. Germino, T. McGonigle, and W. K. Smith. 2005. Variability of Cenococcum colonization and its ecophysiological significance for young conifers at alpine-treeline. New Phytologist 867-873.

Hemstrom, M. A., and J. F. Franklin. 1982. Fire and other disturbances of the forests in Mount Rainier National Park. Quaternary Research 18:32-51.

Hennon, P.E. 1995. Are heart rot fungi major factors of disturbance in gap-dynamic forests. Northwest Science 69:284-293.

Hicks, W.I. 2000. Modeling nitrogen fixation in dead wood. Ph.D. Dissertation. Oregon State University, Corvallis.

Hofgaard, A. 1993. Structure and regeneration patterns in a virgin Picea abies forest in northern Sweden. Journal of Vegetation Science 4:601-60.

Holtmeier, F. 2003. Mountain Timberlines. Kluwer Academic Publishers, Boston.

Holtmeier, F. 2009. Mountain timberlines: ecology, patchiness, dynamics. Advances in Global Change Research 36:5-10.

Holtmeier, F., and G. Broll. 1992. The influence of tree islands and microtopography on pedoecological conditions in the forest-alpine tundra ecotone on Niwot Ridge, Colorado Front Range, USA. Arctic and Alpine Research 24:216-228.

Holtmeier, F. K., and G. Broll. 2005. Sensitivity and response of northern hemisphere altitudinal and polar treelines to environmental change at landscape and local scales. Global Ecology and Biogeography 14:395-410.

Homer, C. C., L.Huang, B. Yang, E. Wylie, and M. Coan. 2004. Development of a 2001 National Land Cover Database for the United States. Photogrammetric Engineering and Remote Sensing 70:829-840.

Johnson, E. A. 1987. The relative importance of snow avalanche disturbance and thinning on canopy plant populations. Ecology 68:43-53.

Kirdyanov, A. V., F. Hagedorn, A. A. Knorre, E. V. Fedotova, E. A. Vaganov, M. M. Naurzbaev, P. A. Moiseev, and A. Rigling. 2012. 20th century tree-line advance and vegetation changes along an altitudinal transect in the Putorana Mountains, northern Siberia. Boreas 41:56-67.

Knapp. A. K. and W. K. Smith. 1982. Factors influencing understory seedling establishment of Engelmann spruce (Picea Engelmannii) and subalpine fir ( $A b$ ies lasiocarpa). Canadian Journal of Botany 60 : 2753-2761.

Körner, C.1989. The nutritional status of plants from high altitudes. Oecologia 81:379-391.

Körner, C. 1998. A re-assessment of high elevation treeline positions and their explanation. Oecologia 115:445-459.
Kramer, M. G., P. Sollins, and R. S. Sletten. 2004. Soil carbon dynamics across a windthrow disturbance sequence in southeast Alaska. Ecology 85:2230-2244.

Kullman, L.2006. Botanical signs of a new and warmer alpine world. Fauna and Flora 104:10-21.

Leung, L. R., and M. S. Wigmosta. 1999. Potential climate change impacts on mountain watersheds in the Pacific Northwest. Journal of American Water Resources Association 35:1463-1471.

Lewis, K. J., and S. B. Lindgren. 1999. Influence of decay fungi on species composition and size class structure in mature Picea glauca, Engelmannii and Abies lasiocarpain sub-borealforests of central British Columbia. Forest Ecology and Management 123:135-143.

Li, M. H., M. F. Xiao, P. Shi, S. G. Wang, Y. D. Zhong, X. L. Liu, X. D. Wang, X. H. Cai, and Z. M. Shi. 2008. Nitrogen and carbon source-sink relationships in trees at the Himalayan treelines compared with lower elevations. Plant, Cell and Environment 31:1377-1387.

Lowery, R. F. 1972. Ecology of subalpine zone tree clumps in the north Cascade Mountains of Washington. Ph.D. Dissertation. University of Washington, Seattle.

Maher, E. L., M. J. Germino, and N. J. Hasselquist. 2005. Interactive effects of tree and herb cover on survivorship, physiology, and microclimate of conifer seedlings at the alpine tree-line ecotone. Canadian Journal of Forest Research 35:567-574.

Malanson, G.P., D. R. Butler, D. B. Fagre, S. J. Walsh, D. F. Tomback, L. D. Daniels, L. M. Rester, W. K. Smith, D. J. Weiss, D. L. Peterson, A. G. Bunn, C. A. Hiemstra, D. Liptzin, P. S. Bourgeron, Z. Shen, and C. I. Millar. 2007. Alpine treeline of western North America and global climate change: linking organism-to-landscape dynamics. Physical Geography 28:378-396.

Markoff, M. F. and A. F. Cullen. 2008. Impact of climate change on Pacific Northwest hydropower. Climatic Change 87:451-469.

Marra, J. L., and R. L. Edmonds. 1996. Coarse woody debris and soil respiration in a clearcut on the Olympic Peninsula, Washington, USA. Canadian Journal of Forest Research 26:1337-1345.

Maser, C., R. G. Anderson, K, Cromack., Jr., J. T. Williams, and R. E. Martin. 1979. Dead and down woody material. In J. W. Thomas (editor), Wildlife habitats in Managed Forests, The Blue Mountains of Oregon and Washington. USDA Forest Service Agricultural Handbook 553, Portland, OR. Pp. 78-95.

Mayer, H., and E. Ott. 1991.Gebirgswaldbau. Schutzwaldpflege. Gustav Fisher, Stuttgart, Germany.

McCarthy, J. 2001. Gap dynamics of forest trees: a review with particular attention to boreal forests. Environmental Reviews 9:1-59.

McNab, W. H., D. T. Cleland, J. A. Freeouf, J. E. Keys, Jr., G. J. Nowacki, C. Carpenter, and C. A. Comps. 
2005. Description of ecological subregions: sections of the conterminous United States. [CD-ROM] Washington, DC: U.S. Department of Agriculture, Forest Service.

Mellmann-Brown, S. 2005. Regeneration of whitebark pine in the timberline ecotone of the Beartooth Plateau, USA: spatial distribution and responsible agents. In G. Broll and B. Keplin (editors), Mountain Ecosystems: Studies in Treeline Ecology. Springer, New York, N.Y.

Mitchell, S. J. 2012. Wind as a natural disturbance agent in forests: a synthesis. Forestry (early access). DOI: 10.1093.forestry/cps058.

Mori A., E. Mizumachi, T. Osono, and Y. Doi. 2004. Substrate-associated seedling recruitment and establishment of major conifer species in an old-growth subalpine forest in central Japan. Forest Ecology and Management 196:287-297.

Mote, P. W. 2003a. Twentieth-century fluctuations and trends in temperatures, precipitation, and mountain snowpack in the Georgia Basin-Puget Sound region. Canadian Water Resources Journal 28:567-585.

Mote, P. W. 2003b. Trends in snow water equivalent in the Pacific Northwest and their climatic causes. Geophysical Research Letters 30:1601.

Mote, P. W., E. A. Parson, A. F. Hamlet, W. S. Keeton, D. Lettenmaier, N. Mantua, E. L. Miles, D. W. Peterson, D. L. Peterson, R. Slaughter, and A. K. Snover. 2003. Preparing for climatic change: the water, salmon, and forest of the Pacific Northwest. Climate Change 61:45-88.

Mote, P. W., A. F. Hamlet, M. P. Clark, and D. P. Lettenmaier. 2005. Declining mountain snowpack in western North America. Bulletin of the American Meteorological Society 86:39-49.

Motta, R., R. Berretti, E. Lingua, and P. Piussi. 2006. Coarse woody debris, forest structure and regeneration in the Valbona Forest Reserve, Paneveggio, Italian Alps. Forest Ecology and Management 235:155-163.

Narukawa, Y., S. Iida, H. Tanouchi, S. Abe, and S. Yamamoto. 2003. State of fallen logs and the occurrence of conifer seedlings and saplings in boreal and subalpine old-growth forests in Japan. Ecological Research 18:267-277.

Noble, I. R. 1993. A model of the responses of ecotones to climate change. Ecological Applications 3:396-403.

Oberhuber, W. 2004. Influence of climate on radial growth of Pinus cembra within the alpine timberline ecotone. Tree Physiology 24:291-301.

Perry, D. A., J. G. Borchers, S. L. Borchers, and M. P. Amaranthus. 1990. Species migrations and ecosystem stability during climate change: the below ground connection. Conservation Biology 4:266-274.

Peterson, D. L. 1998. Climate, limiting factors and environmental change in high-altitude forests of western North America. In M. Beniston and J. L. Innes (editors), The Impacts of Climate Variability on
Forests, Lecture Notes in Earth Sciences. Springer, Berlin, Germany. Pp. 191-208.

Peterson, D. W., D. L. Peterson, and G. J. Ettl. 2002. Growth responses of subalpine fir to climatic variability in the Pacific Northwest. Canadian Journal of Forest Research. 32:1503-1517.

Pyle, C., and M. M. Brown. 1998. A rapid system of decay classification for hardwood logs of the eastern deciduous forest floor. Journal of the Torrey Botanical Society 125:237-245.

R Core Development Team. 2005. R: a language and environment for statistical computing. R Foundation for Statistical Computing, Vienna, Austria. Available online at http://www.R-project.org.

Rochefort, R. M., and D. L. Peterson. 1996. Temporal and spatial distribution of trees in subalpine meadows of Mount Rainier National Park, Washington, USA. Arctic and Alpine Research 28:52-59.

Rochefort, R. M., R. T. Little, A. Woodward, and D. L. Peterson. 1994. Changes in subalpine tree distribution in western North America: a review of climatic and other causal factors. The Holocene 4:89-100

Simard, M. J., Y. Bergeron, and L. Sirois. 1998. Conifer, seedling recruitment in a southeastern Canadian boreal forest: the importance of substrate. Journal of Vegetation Science 9:575-582.

Smith, W. K., and D. M. Johnson. 2007. Limitations to photosynthetic carbon gain in timberline Abies lasiocarpa seedlings during prolonged drought. Canadian Journal of Forest Resources 37:568-579.

Smith, W. K., M. J. Germino, T. E. Hancock, and D. M. Johnson. 2003. Another perspective on Altitudinal limits of alpine timberlines. Tree Physiololgy 23:1101-1112.

Sollins, P. 1982. Input and decay of woody debris in coniferous stands in western Oregon and Washington. Canadian Journal of Forest Resources 12:18-28.

Sollins, P., S. P. Cline, T. Verhoeven, D. Sachs, and G. Spycher. 1987. Patterns of log decay in old-growth Douglas-fir forests. Canadian Journal of Forest Resources 17:1585-1595.

Smit, C., D. Béguin, A. Buttler, and H. Mueller-Schaerer. 2005. Safe sites for tree regeneration in wooded pastures: a case of associational resistance? Journal of Vegetation Science 16:209-214.

Stöckli, B. 1995. Moderholzfür die NaturverjüngungimBergwald, Anleitungzum Moderanbau. Wald Holz 76:16:8-14.

Storaunet, K. O., and J. Rolstad. 2002. Time since death and fall of Norway spruce logs in old-growth and selectively cut boreal forest. Canadian Journal of Forest Resources 32:180-1812.

Thornton, P. E., M. M. Thornton, B. W. Mayer, N. Wilhelmi, Y. Wei, R. B. Cook. 2012. Daymet: Daily surface weather on a $1 \mathrm{~km}$ grid for North America, 1980-2011. Data acquired online (http://daymet. gov/) on 10 November 2010, Oak Ridge National Laboratory Distributed Active Archive Center, 
Oak Ridge, Tennessee, U.S.A. doi:10.3334/ORNLDAAC/Daymet_V2.

Tranquillini, W. 1979. Physiological Ecology of the Alpine Timberline, Springer-Verlag, New York.

Vanha-Majamaa, I., S. Lilja, R. Ryöma, J. S. Kotiaho, and S. Laaka-Lindberg. 2007. Rehabilitating boreal forest structure and species composition in Finland through logging, dead wood creation and fire: the EVO experiment. Forest Ecology and Management 250:77-88.

Veblen, T. T. 1989. Tree regeneration responses to gaps along a transandean gradient. Ecology 70:541-543.

Veblen, T. T., K. S. Hadley, and M. S. Reid. 1991. Disturbance and stand development of a Colorado subalpine forest. Journal of Biogeography 18:707-716.

USDA Natural Resources Conservation Service.2008. Soil Survey, Okanogan National Forest Area, Washington. Available online at: http://soils.usda. gov/survey/printed_surveys/ (accessed online 2 February 2012).

USDA National Resource Conservation Service, National Water and Climate Center. Natural Resources Conservation Service Snowpack Telemetry(SNOTEL) site, Hart's Pass. Available online at: http://www.wcc.nrcs.usda.gov/nwce/ site $?$ sitenum $=515 \&$ state $=w a /($ accessed online 20 January 2012).

van Mantgem, P. J., N. L. Stephenson, J. C. Byrne, L. D. Daniels, J. F. Franklin, P. Z. Fule, M. E. Harmon, A. J. Johnson, J. M. Smith, A. H. Taylor, and T. T. Veblen. 2009. Widespread increase of tree mor-

Received 8 May 2012

Accepted for publication 11 February 2013 tality rates in the western United States. Science 323:521-524.

Wardle, P. 1973. New Zealand timberlines. Arctic and Alpine Research 5:127-136.

Wardle, P. 1981. Winter desiccation of conifer needles simulated by artificial freezing. Arctic and Alpine Research 13:419-423.

Westerling, A. L., H. G. Hidalgo, D. R. Cayan, and T. W. Swetnam. 2006. Warming and earlier spring increase western U.S. forest wildfire activity. Science 313:940-943.

Wilmking M., J. Harden, and K. Tape. 2006. Effect of tree line advance on carbon storage in northwest Alaska. Journal of Geophysical Research 111:1-10.

Wilmking, M., T. Sanders, Y. Zhang, S. Kenter, S. Holzkämper, and P. Crittenden. 2012. Effects of climate, site conditions and seed quality on recent treeline dynamics in northwest Russia: permafrost and lack of reproductive success hamper treeline advance? Ecosystems 15:1053-1064.

Woodward, A., E. G. Schreiner, and D. G. Silsbee. 1995. Geography, and tree establishment in subalpine meadows of the Olympic Mountains, Washington, USA. Arctic and Alpine Research 27:217-225.

Zens, M. S., and D. R. Peart. 2003. Dealing with death data: individual hazards, mortality and bias. Trends in Ecology and Evolution 18:366-373.

Ziolonka T., and M. Niklossen. 2001. Dynamics of dead wood and regeneration pattern in natural spruce forest in the Tatra Mountains, Poland. Ecological Bulletins 49:159-163. 